\title{
PSP toxins from Aphanizomenon flos-aquae (cyanobacteria) collected in the Crestuma-Lever reservoir (Douro river, northern Portugal)
}

Filipa M.B. Ferreira ${ }^{\mathrm{a},}$, José M. Franco Soler ${ }^{\mathrm{b}}$, Maria Leonor Fidalgo ${ }^{\mathrm{a}}$, Pablo FernándezVila $^{\mathrm{c}}$

${ }^{a}$ Laboratory de Parasitologia, Instituto Nacional de Saúde Dr. Ricardo Jorge, Largo 1 de Dezembro, 4000 Porto, Portugal

${ }^{\mathrm{b}}$ Instituto de Investigaciones Marinas (CSIC), E. Cabello, 6, 36208 Vigo, Spain

${ }^{c}$ Centro Galego para o Control da Calidade do Medio Mariño (Xunta de Galicia), Vilaxoan, Pontevedra, Spain

\begin{abstract}
The presence of paralytic shellfish poisoning (PSP) toxins in cultures of Aphanizomenon flos-aquae, isolated from the Crestuma-Lever reservoir, was found by reversed phase high performance liquid chromatography employing two isocratic elution systems for the separation of PSP toxins. With the first isocratic elution protocol, the presence of apolar toxins as saxitoxin, decarbamoyl saxitoxin and neosaxitoxin not detected. On the other hand, GTX4, GTX1 and GTX3 as well as Cs toxins were present either in the Aphanizomenon flos-aquae cells collected directly from the bloom or in the other toxic isolates priorly cultivated in laboratory conditions.
\end{abstract}

Keywords: PSP toxins; RP-HPLC; Aphanizomenon; Cyanobacteria

\section{Introduction}

Cyanobacteria, also called blue-green algae, are common and natural components of most aquatic ecosystems. Blooms of cyanobacteria are becoming prevalent in municipal water supplies, swimming areas, and aquaculture zones affected by increasing nutrient levels resulting from runoff of fertiliser livestock or human wastes. Toxic water blooms can be found in many waterbodies throughout the world which may be responsible for sporadic but repeated episodes of animal poisonings from certain municipal and recreational water supplies (Skulberg et al., 1984; Repavich et al., 1990; Sivonen et al., 1990; Edwards et al., 1992; Kotak et al., 1993; Rao et al., 1994; Fawks et al., 1994; 
Vasconcelos, 1994; Negri et al., 1995). Themain toxic cyanobacterial genera include filamentous Anabaena, Aphanizomenon, Nostoc, Nodularia, Oscillatoria, and unicellular colonial Microcystis and Lyngbya (Skulberg et al., 1984; Ikawa et al., 1985; Carmichael, 1988; English et al., 1993; Negri et al., 1995; Onodera et al., 1995; Carmichael et al., 1997).

In the past two decades public hazards and economic impacts of alga blooms appear to have increased in frequency, intensity, and geographical distribution (Alam et al., 1973; Jackim and Gentile, 1968; Mahmood and Carmichael, 1986; Onodera et al., 1996). Moreover, blooms of toxic cyanobacteria cannot always be prevented or controlled in water bodies, since intact cyanobacterial cells together with the associated toxins cannot be easily removed. In addition, consumption of low doses of cyanobacterial toxins in drinking water is suspected of contributing to a high rate of human disorders (for instance, microcystins are thought to be liver tumour promoters) (Falconer et al., 1983, Nishiwaki et al., 1991; Rabergh et al., 1991; Carmichael, 1994). In this context a relevant effort has been developed by several authors aiming to improve water treatment processes for the removal of toxins from water (Keijola et al., 1988; Watanabe et al., 1992; Kenefick et al., 1993).

The cyanobacterial toxins that have been studied intensively to date belong to one of three groups (alcaloide neurotoxins, alkaloid hepatotoxins and hepatotoxic peptides), defined by the symptoms that they have produced in animals. Saxitoxin (STX) and neosaxitoxin (neoSTX) that were shown to be the major neurotoxins present in blooms of Aphanizomenon flos-aquae occurring occasionally in freshwaters are known to produce STX and neoSTX, toxins commonly associated to dinoflagellates (Mahmood and Carmichael, 1986). More recently, STXs have been found in other cyanobacteria such as Anabaena circinalis, Oscillatoria mougeotti, and Lingbya wollei which produce a complex STX profile with Cs, GTXs, dcGTXs, decarbamoyl saxitoxin (dcSTX) and STX (Negri et al., 1995, Carmichael et al., 1997; Onodera et al., 1997).

This paper deals with the presence of STXs in A. flos-aquae strains isolated by reversed phase high performance liquid chromatography (RP-HPLC) from the Crestuma-Lever reservoir in north of Portugal (Europe). 
2. Materials and methods

The water body sampled in this study was the Crestuma-Lever reservoir, located in the lower part of the Douro River, $20 \mathrm{~km}$ upstream from the city of Porto, in Portugal (Fig. 1A). The reservoir has an area of 1298 ha, a total volume of 109 million cubic metres, and a mean depth of $13 \mathrm{~m}$. There are three water intake towers for drinking water, which are located 1500, 2000, and $2500 \mathrm{~m}$ upstream from the dam. In order to get laboratory cultures, from July to December 1996, the reservoir was monthly sampled at five station points, three of them located near the water intake towers and the other two at sheltered sites of the left bank of the reservoir.

A. flos-aquae cells obtained directly from the bloom and from the three isolates (IZAN1, IZAN2, and IZAN3) collected in the reservoir were then cultivated in Z8 medium (Skulberg et al., 1984), in 61 batch-culture flasks and maintained at $20 \pm 1^{\circ} \mathrm{C}$, under continuous light from a cool white fluorescent lamp $\left(60 \mu \mathrm{E} / \mathrm{m}^{2} / \mathrm{s}\right)$, and aerated at a flow rate of $21 / \mathrm{h}$. In the five station points, from July to December 1996, we isolated three different strains. Cells were harvested after 2 weeks of continuous growth by decantation, and stored as frozen or lyophilised samples. Extraction of the samples was achieved with $0.1 \mathrm{M}$ acetic acid. These extracts were evaporated to dryness and dissolved in $2 \mathrm{ml}$ of $0.1 \mathrm{M}$ acetic acid and the $\mathrm{pH}$ was adjusted to 2 with $5 \mathrm{M} \mathrm{NaOH}$ or $0.1 \mathrm{M} \mathrm{HCl}$.

Toxicity of the cell extract (either from the bloom or from the three isolated strains) was tested by mouse bioassay by the AOAC (1990) method: $1 \mathrm{ml}(0.3 \mathrm{~g})$ of A. flos-aquae lyophilised cells was intraperitoneally injected to male Charles River mice (20-25 g). Animals were observed for $4 \mathrm{~h}$ and signs of poisoning recorded.

Toxin separation was done by an RP-HPLC method (Franco and Fernández-Vila, 1993). Two isocratic elutions were used. In the first, for separation of carbamate toxins, neoSTX, dcSTX and STX, the elution was with $1.5 \mathrm{mM}$ octanesulfonate in $10 \mathrm{mM}$ ammonium phosphate buffer ( $\mathrm{pH}$ 7.2) plus $6 \%$ acetonitrile. The second system for GTX toxin separation was with $2 \mathrm{mM}$ octanesulfonate in $10 \mathrm{mM}$ ammonium phosphate buffer ( $\mathrm{pH} 7.0$ ), at $0.8 \mathrm{ml} / \mathrm{min}$, in both systems. Detection was fluorimetric using a postcolumn oxidation. 
Estimation of toxin concentrations in the Aphanizomenon cell extracts was achieved by the integration of the peak areas corresponding to toxins detected by the RP-HPLC system and comparing them with known concentrations of an STX standard and a quantified extract of a culture of the marine dinoflagellate Alexandrium minutum (Al 1V). The standard of GTXs (GTX1-4) was supplied by the National Research Council Canada (NRCC, 1999) and a secondary standard from purified extracts of Alexandrium minutum cultures, strain Al $1 \mathrm{~V}$ calibrated with the NRCC standard of GTXs. The standards of dcSTX, STX, and neoSTX used for identification and quantification of these toxins were supplied by the project EUR 18318 of the European Commission.

\section{Results and discussion}

The A. flos-aquae cells used in this study were found at four of the five points sampled, but only two strains, IZAN1 and IZAN2, and the cells collected directly from the bloom were toxic. From July to December we observed a seasonal variation in the cyanobacterial community in the studied reservoir (Table 1). From July to August, A. flos-aquae was the only cyanobacterial species found in the phytoplankton samples. In September and October apart from A. flos-aquae, Microcystis aeruginosa was also found. In November, only M. aeruginosa was found, while in December none of these two cyanobacterial species were observed. No thermal stratification is observed in the Crestuma-Lever impoundment throughout the year. This probably contributes to the lack of phytoplancton stratification and may increase the possibility of Aphanizomenon cells and paralytic shellfish poisoning (PSP) toxins reaching the intake lines.

The external symptoms observed in the mouse bioassays were ascendant paralysis, lack of any involuntary reaction, pale ears, exophthalmus and death in 8-15 min. Concerning the internal symptoms, only a pooling of blood was recorded. It has to be emphasised that these symptoms differed from those referred to in the available literature as being characteristics of the PSP toxins, mainly the ascendant paralysis symptom (Mahmood and Carmichael, 1986; Humpage et al., 1994).

From the HPLC analysis the following details can be observed: in the first isocratic system the presence of apolar toxin was not detected (Fig. 2A-C). Analysing GTXs 
distribution and comparing it with the second isocratic system, the standard A11V and the corresponding acid treatment, four peaks can be seen: the first, second, and third peaks corresponding to GTX4, GTX1, and GTX3, respectively (Fig. 2D-F). The almost total disappearance of the first peak (Fig. 2E) as shown in Fig. 2F, indicates the presence of Cs toxins. Although we isolated A. flos-aquae directly from the bloom and from the toxic isolates (cultivated in laboratory), the toxin profiles were similar.

The estimated toxin concentrations in the Aphanizomenon samples (Table 2) for GTX4, GTX1, and GTX3 were 14.1, 3.6, and $0.5 \mu \mathrm{g} / \mathrm{g}$ (dry weight), respectively; the amount of GTX4 corresponding approximately to $4.7 \mu \mathrm{g}$ STX equivalents/g (Oshima, 1995).

Given that shellfish containing more than $0.8 \mu \mathrm{g}$ STX equivalents/g (wet weight) of meat (Falconer, 1993) are considered unfit for human consumption, $4.7 \mu \mathrm{g}$ STX equivalents/g (dry weight) of Aphanizomenon cellular extracts are more than sufficient to be the primary cause of death in mice.

These results are consistent with the qualitative and quantitative analysis of STXs found in A. circinalis (Negri et al., 1995) and in L. wollei (Carmichael et al., 1997; Onodera et al., 1997).

For many years A. flos-aquae was thought to be the only cyanobacterial species producing these toxins. The recent finding that A. circinalis in Australia also produces these toxins (Onodera et al., 1997), may be an indication that PSP toxins could be produced by other cyanobacteria. In Portugal, although cyanobacterial neurotoxins are not as common as hepatotoxins, namely microcystins (Araújo, 1995), further research work is needed on this matter in order to monitor and control their presence in water supplies.

Acknowledgements

This work was partially supported by a grant from Fundaçao para a Ciência e Tecnologia (FCT) to Dr. F.M.B. Ferreira and CICYT project ALI 92-0111-C02-01.

\section{References}


Alam, M., Ikawa, M., Sasner Jr., J.J., Sawyer, P.J., 1973. Purification of Aphanizomenon flos-aquae toxin and its chemical and physiological properties. Toxicon 11, 65-72.

Araújo, F.O., 1995. Cyanobacteria blooms in Portugal, management of public health problems. 1st International Congress on Toxic Cyanobacteria, Ronne, Denmark Association of Official Analytical Chemists (AOAC), 1990. Method 959-08. Official Methods of Analysis, 15th ed., vol. 2. Association of Official Analytical Chemists, Arlington, VA, pp. 881-882

Carmichael, W.W., 1988. Toxins of freshwater algae. Tu, A.T. (Ed.), Handbook of Natural Toxins, Marine Toxins and Venoms, vol. 3. Marcel Dekker, New York, pp. 121-147.

Carmichael, W.W., 1994. The toxins of cyanobacteria. Sci. Am. 270 (1), 64-72.

Carmichael, W.W., Evans, W.R., Yin, Q.Q., Bell, P., Mocauklowski, E., 1997. Evidence for paralytic shellfish poisons in the freshwater cyanobacterium Lyngbya wollei (Farlow ex Gomont) com. nov.. Appl. Environm. Microbiol. 63, 3104-3110.

Edwards, C., Beattie, K.A., Scrimgeour, C.M., Codd, G.A., 1992. Identification of anatoxin-a in benthic cyanobacteria (blue-green algae) and in associated dog poisonings at Loch Insh, Scotland. Toxicon 30 (10), 1165-1175.

English, W.R., Schwedler, T.E., Dick, L.A., 1993. Aphanizomenon flos-aquae, a toxic blue-green alga in commercial channel catfish Ictalurus punctatus ponds: a case history. J. Appl. Aquacult. 3 (1/2), 195-209.

Falconer, I.R., Beresford, A.M., Runnegar, M.T.C., 1983. Evidence of liver damage by toxin from a bloom of the blue-green alga Microcystis aeruginosa. Med. J. Aust. 1, 511-514.

Falconer, I.R., 1993. Measurement of toxins from blue-green algae in water and foodstuffs. Algal Toxins in Seafood and Drinking Water. Academic Press, London.

Fawks, D.J., Kotak, B.G., Jones, J.R., Prepas, E.E., 1994. Occurrence of hepatotoxic blue-green algae in Missouri reservoirs. Lake Reserv. Manage 9 (2), 72.

Franco, J.M., Fernández-Vila, P., 1993. Separation of paralytic shellfish toxins by reversed phase high performance liquid chromatography with postcolumn reaction and fluorimetric detection. Chromatographia 35 (9-12), 613-620.

Humpage, A.R., Rositano, J., Bretag, A.H., Brown, R., Baker, P.D., Nicholson, B.C., Steffensen, D.A., 1994. Paralytic shellfish poisons from Australian blue-green algal (cyanobacterial) blooms. Aust. J. Mar. Freshwat. Res. 45, 761-771. 
Jackim, E., Gentile, J., 1968. Toxins of a blue-green alga: similarity to saxitoxin. Science 162, 915-916.

Ikawa, M., Auger, K., Mosley, S.P., Sasner, J.J., Noguchi, T., Hashimoto, K., 1985. Toxins profiles of the blue-green alga Aphanizomenon flos-aquae. In: Anderson, White, Baden (Eds.). Toxic Dinoflagellates. Elsevier, Amsterdam, pp. 299-305. Keijola, A.M., Himberg, K., Esala, A.L., Sivonen, K., Hiisvirta, L., 1988. Removal of cyanobacterial toxins in water treatment processes: laboratory and pilot-scal experiments. Toxicity Assessment: An International Journal 3, 643-656.

Kenefick, S.L., Hrudey, S.E., Petersen, H.G., Prepas, E.E., 1993. Toxin release from Microcystis aeruginosa after chemical treatment. Water Sci. Technol. 27 (3/4), 433 440.

Kotak, B.G., Kenefick, S.L., Fritz, D.L., Rousseaux, C.G., Prepas, E.E., Hrudey, S.E., 1993. Occurrence and toxicological evaluation of cyanobacterial toxins in Alberta lakes and farm dugouts. Water Res. 27 (3), 495-506.

Mahmood, N.A., Carmichael, W.W., 1986. Paralytic shellfish poisons produced by the freshwater cyanobacterium Aphanizomenon flos-aquae NH-5. Toxicon 24 (2), 175186.

National Research Council of Canada's (NRCC) 1999. Certified Reference Materials Program (CRMP). Shellfish toxins Đ standards and references materials. Institute for Marine Biosciences, Halifax, Nova Scotia.

Negri, A.P., Jones, G., Blackburn, S., 1995. Studies on PSP toxins in Australian freshwater cyanobacteria. VII Internat. Conference on Toxic Phytoplancton, p. 99. Nishiwaki, M.R., Nishiwaki, S., Ohta, T., Yoshizawa, S., Suganuma, M., Harada, K., Watanabe, M.F., Fujiki, H., 1991. Structure-function relationships of microcystins, liver tumor promoters, in interaction with protein phosphatase. Jap. J. Cancer Res. $82(9), 993-996$.

Onodera, H., Oshima, Y., Yasumoto, T., Watanabe, M.F., Watanabe, M., Negri, Ap., Blackburn, S., 1995. Production of PSP toxins by cyanobacteria. VII Internat. Conference on Toxic Phytoplancton, p. 100.

Onodera, H., Oshima, Y., Watanabe, M.F., Watanabe, M., Bolch, C.J., Blackburn, S., Yasumoto, T., 1996. Screening of paralytic shellfish toxins in freshwater cyanobacteria and chemical confirmation of the toxins in cultured Anabaena circinalis from Australia. In: Yasumoto, T., Oshima, Y., Fukuyo, Y. (Eds.). Harmful and Toxic Algal Blooms. Lavoisier, Paris, pp. 475-480. 
Onodera, H., Satake, M., Oshima, Y., Yasumoto, T., Carmichael, W.W., 1997. New saxitoxin analogues from the freshwater filamentous cyanobacterium Lyngbya wollei. Nat. Toxins 5, 146-151.

Oshima, Y., 1995. Postcolumn derivatization liquid chromatography method for PSP toxins. JAOAC 78 (2), 528-532.

Rabergh, C.M.I., Bylund, G., Eriksson, J.E., 1991. Histopathological effects of microcystin-LR, a cyclic peptide toxin from the cyanobacterium (blue-green alga) Microcystis aeruginosa on common carp (Cyprinus carpio L.). Aquat. Toxicol. 20 (3), 131-146.

Rao, P.V.L., Bhattacharya, R., Gupta, S.D., 1994. Isolation, culture and toxicity of the cyanobacterium (blue-green alga) Microcystis aeruginosa from a freshwater source in India. Bull. Environm. Contam. Toxicol. 52 (6), 878-885.

Repavich, W.M., Sonzogni, W.C., Standridge, J.H., Wedepohl, R.E., Meisner, L.F., 1990. Cyanobacteria (blue-green algae) in Wisconsin waters: acute and chronic toxicity. Water Res. 24 (2), 225-231.

Sivonen, K., Niemela, S.I., Niemi, R.M., Lepisto, L., Luoma, T.H., Rasanen, L.A., 1990. Toxic cyanobacteria (blue-green algae) in Finnish fresh and coastal waters. Hydrobiologia 190 (3), 267-275.

Skulberg, M.O., Codd, G.A., Carmichael, W.W., 1984. Toxic blue- green algae in Portuguese fresh waters. Arch. Hydrobiol. 130 (4), 439-451.

Vasconcelos, V.M., 1994. Toxic cyanobacteria (blue-green algae) in Portuguese fresh waters. Arch. Hydrobiol. 130 (4), 439-451.

Watanabe, M.F., Tsujii, K., Watanabe, Y., Harada, K.I., Suzuki, M., 1992. Release of heptapeptide toxin (microcystin) during the decomposition process of Microcystis aeruginosa. Nat. Toxins 1 (1), 48-53. 


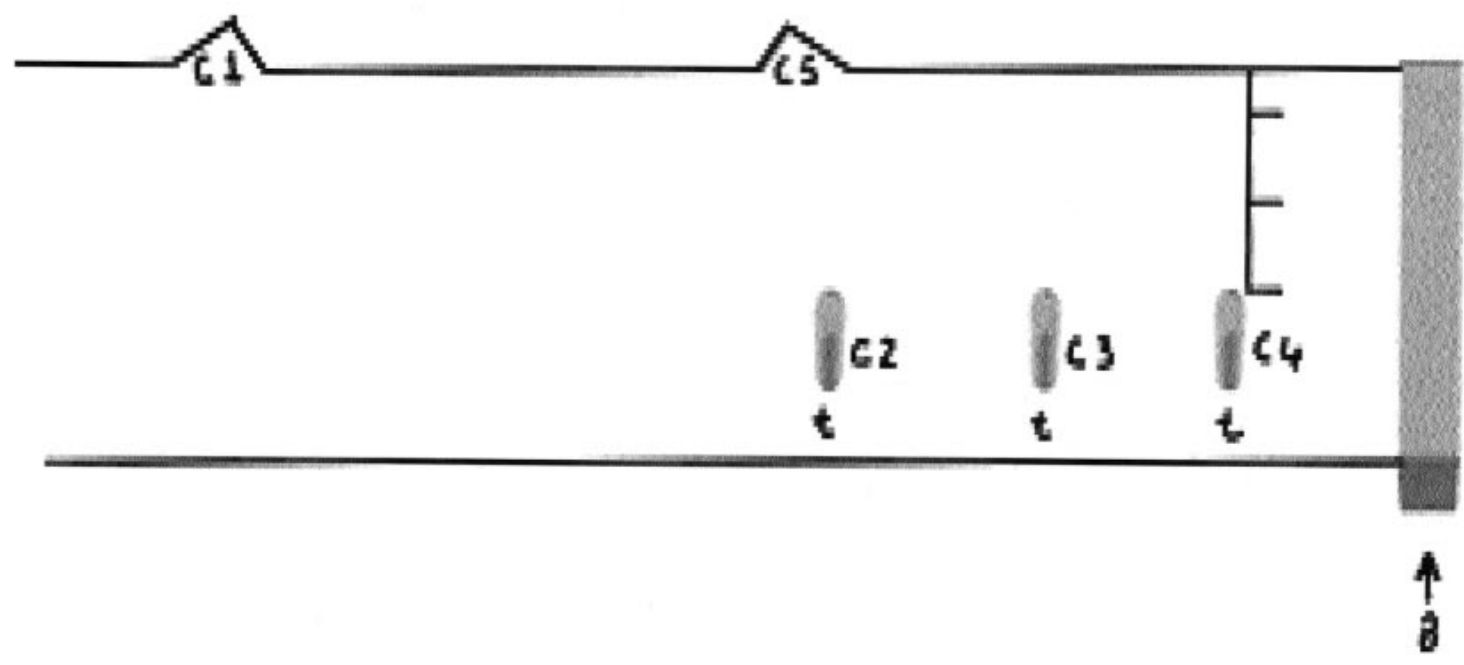

Fig. 1. A - Map of the study area localisation; B - sample points located in CrestumaLever reservoir (Douro River); (Legend: C1-C5 - sample points; $b$ - impoundment; $t$ water intakes).

Fig. 2. First isocratic elution system: A - STX standard; B - extract of Aphanizomenon flos-aquae; $\mathrm{C}$ - extract of Aphanizomenon flosaquae acid hydrolised. Second isocratic elution system: D - Standard Al 1V from Alexandrium minutum; E - extract as B; F extract as C (Cs: C toxins, $\mathrm{U}$ : fluorescent material no toxic).

Table 1. A. flos-aquae distribution according to the sample station in the CrestumaLever reservoir since July to December ${ }^{\mathrm{a}}$

\begin{tabular}{|c|c|c|c|c|c|c|}
\hline \multirow[t]{2}{*}{$\begin{array}{c}\text { Months } \\
\text { (1996) }\end{array}$} & \multicolumn{5}{|c|}{$\begin{array}{c}\text { Sample points (according to } \\
\text { Fig. 1B) }\end{array}$} & \multirow[t]{2}{*}{ Isolated species } \\
\hline & C1 & $\mathrm{C2}$ & $\mathbf{C 3}$ & $\mathrm{C4}$ & C5 & \\
\hline & A & A & - & A & A & A. flos-aquae (IZAN1) \\
\hline ust & A & $\mathrm{A}$ & - & A & $\mathrm{A}$ & A. flos-aquae (IZAN2) \\
\hline ptember & $\mathrm{A}, \mathrm{M}$ & $\mathrm{A}, \mathrm{M}$ & $\mathrm{M},-$ & $\mathrm{A}, \mathrm{M}$ & $\mathrm{A}, \mathrm{M}$ & $\begin{array}{l}\text { A. flos-aquae bloom, } M \text {. } \\
\text { aeruginosa }\end{array}$ \\
\hline ctober & A & A & $\mathrm{M},-$ & A & A & $\begin{array}{l}\text { A. flos-aquae (IZAN3) } M \text {. } \\
\text { aeruginosa }\end{array}$ \\
\hline ovember & M & M & $\mathrm{M},-$ & M & M & M. aeruginosa \\
\hline
\end{tabular}




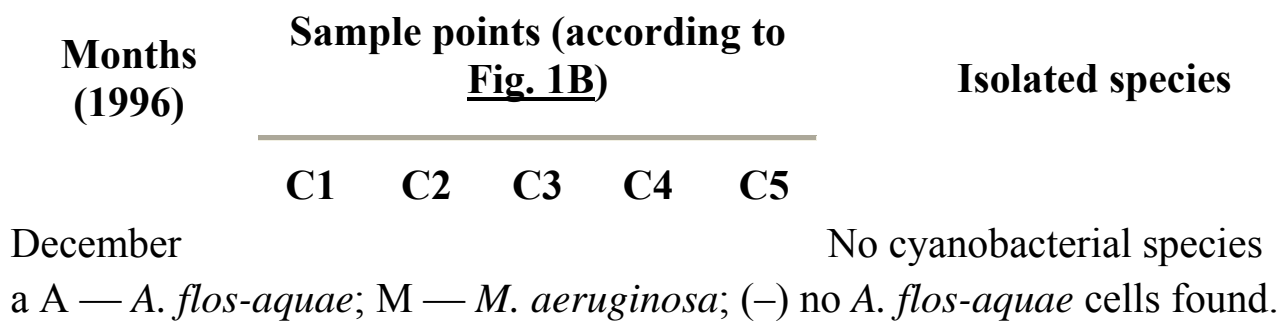

Table 2. Toxins present in the A. flos-aquae samples collected in Crestuma-Lever reservoir

\begin{tabular}{|c|c|c|}
\hline & $\begin{array}{l}\text { GTXs } \mu g / g(d r y \\
\text { weight) }\end{array}$ & $\begin{array}{c}\mu \mathrm{g} \text { STX equivalents/g (dry } \\
\text { weight) }\end{array}$ \\
\hline GTX4 & 14.1 & $4.7^{\mathrm{a}}$ \\
\hline GTX1 & 3.6 & \\
\hline GTX3 & 0.5 & \\
\hline GTX2 & None & \\
\hline $\begin{array}{l}\text { Injected volume in RP- } \\
\text { HPLC }\end{array}$ & $15 \mu l$ & \\
\hline
\end{tabular}

